\title{
INFLUENCE OF PENSION FUNDS AND LIFE INSURANCE ON OLD-AGE PENSION
}

\author{
Danguolè JABLONSKIENĖ \\ Mykolas Romeris University \\ Ateities str. 20, LT-08303 Vilnius, Lithuania \\ E-mail: danguole.j@jablonskis.lt \\ doi:10.13165/IE-13-7-3-08
}

\begin{abstract}
The situation of SoDra (State social insurance) in Lithuania is very complicated, thus the Lithuanian Parliament, the Lithuanian Government, and all citizens of Lithuania are becoming more aware of the state of current and future pensioners that is in need of acute rearrangement. Furthermore, that fact is confirmed by the changes of the pension system reform launched on 1 January 2013. Lithuania's economy is still largely affected by the economic crisis, but before the crisis the country did not build the base of traditions characteristic to the Western world. In the developed countries of Western Europe, when a child is born, a pension fund and life insurance contract is concluded. During this period from birth to death, a solid private sum of money is accumulated, which allows making a living and not changing the lifestyle one has been living until retirement. For instance, in Germany a state pension is about 1100 Euros, and a private one amounts to 4500-5500 Euros per person. Therefore, we can assume that the main source of living in elderly age is a private and not a state pension. On the contrary, in Lithuania the main source of living is a state pension. Though the Lithuanian government encourages long-term accumulation by introducing tax privileges for individuals who have signed their pension accumulation and life insurance contracts, this is not enough. The decrease of average earnings does not prompt the accumulation for the future, as simply there is no such amount available. Moreover, the increase of unemployment in the country and emigration are important factors as well. Thus, aiming for steady pension income shaping, economic and business growth and decrease of unemployment is necessary. No less important is education of the public to the effect that life at old age is highly dependent not only on the state's contribution but also on each future pensioner's personal contribution.
\end{abstract}

JEL classification: $\mathrm{H} 55$.

Keywords: social health insurance, pension, pension system reformation, life insurance, second and third step pension funds.

Reikšminiai žodžiai: valstybinis socialinis draudimas, senatvès pensija, pensijų sistemos reforma, gyvybès draudimas, antros ir trečios pakopos pensijų fondai. 


\section{Introduction}

This article discusses the Lithuanian citizens' sources for creating a pension, the situation of SoDra, the pension system reform, its establishment process, changes made according to difficult economic situation and changes introduced in 2013. The Soviet Union heritage has strongly affected and still affects the Lithuanian citizens' approach towards their future. During the Soviet period, people were told that the government would take full care of everyone's future. For a while it worked perfectly, but the existing situation tells us that the government is not in a position to provide stable social guarantees that would determine good living. Pension fund and life insurance specialists undertake efforts to educate people, so that they understand the need to take care of their own future. Many people are disappointed with unstable economy, high unemployment in the country, decreasing income per person, therefore, few people trust the well-tested methods offered by pension funds and insurance companies. The pension system reform launched on 1 September 2003 is nevertheless approached quite contradictorily. Although the government policy towards pension funds is not solid and does not enable a smooth process of the reform, more and more people understand the benefits of private pension funds and life insurance. Serious problems of social care originate from the deteriorating demographic situation and the intensive emigration from the country. The number of people able to work, whose tax payments assure social guarantees for retired individuals is decreasing. This leads to people's concern over their own and their children's future.

The article analyses the factors affecting the old-age pension formation and the reasons for this, discusses the market development perspective, also the implementation of the pension system reform and its changes from 1 January 2013.

\section{Theme and Urgency of the Problem}

The theme is extremely relevant because of the demographic situation in Lithuania and the serious crisis affecting the Lithuanian social security system. Pension funds and life insurance are great tools to create additional social guarantees for any family. This financial support is provided in case of an accident or sickness, it also gives an opportunity to accumulate money needed for offspring education and a way to form a substantial old-age pension.

Despite this, in Lithuania many people are sceptical about the pension system reform and pension funds. In the developed western countries it is natural to conclude life insurance and pension fund accumulation contracts for the newborn, while in Lithuania people are still waiting that the government takes care of their future financially.

The aim of the article is to determine and analyse the sources needed for formatting an old-age pension, discuss the perspectives of the pension system reform and its influence on the old-age pension.

Tasks of the article:

1. Analyse future constituent parts of the old-age pension.

2. Discuss the characteristics of the Lithuanian pension system reform

3. Discuss the perspectives of the Lithuanian pensioners. 
The object of the test is the Lithuanian citizens' pension

\section{Testing methods:}

- Statistical data analysis

- Comparative analysis

- Quantitative analysis method

- Scientific literature analysis and summary

\section{State Social Insurance System in Lithuania}

For many years state social insurance has been and still is one of the most important constituents of the social security system in Lithuania. It is almost an integral part of each resident, accompanying a person throughout his or her entire life and appearing "self-evident". A state social insurance fund (SoDra) was established to implement social insurance. SoDra has been implementing public social insurance for over 20 years now, by guaranteeing income for those covered by state insurance, for people unable to work because of sickness, parenthood, old age, disability or in other cases foreseen by the law, aimed at decreasing or compensating the income lost because of unemployment. The state social insurance system is based on generation solidarity "pay-as-you-go" principle, where the collected payments are distributed at once. Therefore, it is very closely related to the country's economic potential. From 2008 onwards, the country's pace of economic growth began slowing down, unemployment was rising, enterprises were going bankrupt, the economy experienced one recession after another. It greatly affected the social insurance system. The main functions of the state social insurance fund ("the Fund") administration- is to organise social insurance, regulate the means of the operative fund and keep the accounting, ensure the collection and exaction of state social insurance payments, secure the regulation of data on the insurers and insurants, also allocate and pay social insurance payments to beneficiaries.

The Board of the Fund seeks to determine social insurance of the Lithuanian residents by governing the financial sources effectively and by providing quality services to its customers, as guaranteed by the Lithuanian laws.

As referred above, the Lithuanian state insurance system leans on the principles of solidarity and "pay-as-you-go". This means that employed people paying social insurance payment to the Fund's budget guarantee income for those unable to work because of the social risks foreseen by the law. The collected social insurance payments are not accumulated or invested, but at once distributed to the beneficiaries of particular social insurance payments (pensions and other payments).

\section{Types of State Social Insurance}

As many other countries, Lithuania has the following legitimised types of social insurance:

- Pension insurance, where the main or the main and the additional pension is insured; 
- Sickness and motherhood social insurance, where one is covered to obtain a sickness and parenthood, professional rehabilitation payment or in cases foreseen by the State Social Insurance Law to obtain only motherhood or parenthood payments;

- Unemployment social insurance, where a person is covered for an unemployment social insurance payment;

- Accidents at work and professional sickness social insurance, where a person is covered for payments foreseen by the Lithuanian Law on accidents at work and professional diseases;

- Health insurance, where a person is covered for health services and compensation.

Individuals not covered by the obligatory state social insurance in accordance with the procedure foreseen by the law are able to obtain public voluntary social pension insurance and social insurance for sickness and motherhood payments. In case of voluntary insurance, they are insured individually, by concluding contracts with territorial departments and by paying according to the size of social insurance payments in line with their contract.

\section{Insurers and Insurants}

The Law on State Social Insurance provides that state social insurance payments must be paid by:

- Insurants - all public and private legal persons obliged to calculate, deduct and pay state social insurance payments to the State Social Insurance Fund budget, also natural persons who themselves have to pay state social insurance payments in accordance with the procedure set by the Lithuanian Government;

- owners of individual enterprises; self-employed individuals, including lawyers, assistant lawyers, bailiffs, scriveners, farmer community members, real commandite farmer community members; individuals holding business certificates and farmers and business partners, where, according to the calculations applicable on the last day of the previous year, the economic size of the land farm domain amounts to or exceeds 4 economic quantity units.

\section{Individuals Covered by all Types of Social Insurance}

- Individuals working under employment contracts, candidate notaries (assessors), individuals working on the basis of compensable membership, elected position or individuals appointed to municipality, also other persons.

More detailed information can be found at the website of the State Social Insurance Fund website: http://www.sodra.lt/.

\section{State Social Insurance Payment Tariff}

Confirmed state social insurance tariffs for 2012:

Insurer's state pension, sickness and motherhood, unemployment social insurance and health insurance payment tariff is $30.8 \%$ and its amounts for particular social insurance types are: 
- Pension social insurance - 2.3\%;

- Sickness and motherhood social insurance - 3.4\%;

- Unemployment social insurance- $1.1 \%$;

- Health insurance - 3\%.

The tariff for covered individuals' social insurance and health insurance payments is $9 \%$, and its amounts according to separate parts of social insurance types:

- pension social insurance - 3\%;

- health insurance $-6 \%$.

The tariff for accidents at work and professional sickness social insurance payments amounts to $0.2 \%$ and for payment tariff groups of accidents at work and professional sickness social insurance and for these groups attributed insured individuals' paid accidents at work and professional sickness social insurance payment tariff:

- group I-0.18\%;

- group II - 0.42\%;

- group III - 0.9\%;

- group IV $-1.8 \%$.

More detailed information can be found on the website of the State Social Insurance Fund: http://www.sodra.lt/.

\section{Why the Pension System Reform is Necessary?}

According to the applicable provisions of the state social insurance law, in Lithuania an average old-age pension for those who have the required job experience currently amounts to about LTL 830.

It is four to five times less than the average pension in the developed Western European countries.

Based on the material covered in the first chapter of the article and comparing to the livelihood rate in Lithuania we can make a conclusion that the payments to the state social insurance fund are increasing, the list of covered individuals is expanding because of the SoDra budget deficit, the number of working people is decreasing because of emigration and unemployment, and the number of socially supported individuals is increasing constantly.

Social support payments are very small, they entail many restrictions. For example, money paid in case of disability does not amount to $100 \%$ of the salary. Furthermore, currently a widow's pension is LTL 70, which does not amount to real support for the family.

Increasing payments to the state social insurance fund place a heavy burden for businesses. Possibly, in order to survive the hardship brought by 2009-2012, some businesses started operating in "shadow" economy. It became even harder to collect the money to the fund.

Up to 2012, the pensionable age for women was 60 years, and for men it was 62.5 years respectively.

As of 1 January 2012, the pensionable age is set by the provisions of Articles 21 and 57 of the applicable State Social Insurance Pension Law (9 June 2011. Law in the ver- 
sion No XI-1436 published in the Official Gazette Valstybès Žinios, 28-06-2011, No 77, publication No 3723).

Anyone can calculate their own pensionable age by using the following link:

http://www.sodra.lt/amziaus_skaiciuokle

A traditional pension system financed by the state is negatively influenced by the ageing European residents. The changing ratio between pensioners and working people could not be fixed only by means of the "pay-as-you-go" type of distribution.

In 1881, Otto von Bismarck created a pension system that corresponded to the nowadays model of SoDra. But what factors assured the functionality of the system by now?

Many factors determined the system's functionality. Some of them were:

1. High fertility

2. Large number of working individuals

3. $100 \%$ employment possibility for young people after graduating from a university.

4. Early mortality of pensioners ( 1 in 3 European men do not reach their old age)

5. Low unemployment rate.

Current life strongly influenced the factors listed above. According to the Global Allianz Investors research conducted in the Central and Eastern Europe, SoDra's calculated old-age pension will amount to only 30 to $35 \%$ of one's income. The economists have calculated that an individual who has reached their old age is able to live on equal conditions only with $80 \%$ of one's previous income. The existing situation results in $50 \%$ lack of income, which can push the majority of old age people below poverty level.

This social maintenance system is inefficient and is in need of acute reform.

\section{Benefit of the Pension System Reform for Pensioners}

Politicians had been long discussing the need to change the pension system. Many political groups were for the creation of pension funds. The question of implementation of the pension fund system was included in the Government's programme plan. The largest employer groups also agreed with it. Interestingly, the trade unions remained passive on this issue. That was the reason that it took some time before it was decided to make additional accumulation in the pension funds. The Parliament approved the resolution for the pension provision reform. One week after the Government agreed to introduce the pension system reform, which provided for the voluntary accumulation insurance pension, governed private pension funds, no increase of the insurance tariff, meaning that a part of the social insurance tariff is transferred for the accumulation for pension funds.

The II level pension system in Lithuania became effective on 1 September 2003. It was launched much earlier in Poland and other neighbouring countries. In those countries, the reform was partially compulsory - for younger market participants, according to certain arrangements, a part of their social insurance tax was redirected to private pension funds. Middle-aged employees could choose if they wanted to trust only the state social insurance system or have a part of their money transferred to private funds. Residents of the neighbouring countries are rather eager to use this new opportunity. During the first two years of the reform in Poland, $63 \%$ of middle-aged people signed contracts with the 
funds. In Estonia, more than half of working people were interested in accumulating their pensions in private funds. In Latvia, a number of people eager to participate in the reform is increasing constantly. According to specialists, the system was popular because of the activity of pension funds in the new market. Until 1999, in Poland a state old-age pension was the only source of income. The state system was reconstructed due to the need to decrease the expenses of the country and in order to create a certain environment, in which a private accumulation system would be able to develop, to be financed by working people under age 30 and individuals under age 50 who chose this system voluntarily. Payments in Poland amount to about $7.3 \%$ of the employee's wage.

The reform of the pension system in Lithuania began on 1 September 2003.

The pension reform in Lithuania was launched in order to reach the following goals:

- provide conditions for the insured to receive bigger pensions;

- decrease the influence of population ageing on the pension system;

- gradually decrease the pension insurance tariff and thereby decrease the price for the workforce;

- strengthen the accumulation market and encourage growth of Lithuania's economy.

The essence of the pension system reform is the transition from the existing pension system, based on the distribution of the collected funds, to the system based on accumulation. As of 1 January 2004, each person covered by the compulsory state social insurance is be able to accumulate a part of the pension in private account held in a chosen pension fund. The pension system reform is voluntary, this means that everyone can decide whether to earmark a part of their finances to a chosen pension fund.

Until 1 January 2013, individuals who decided to participate in the accumulation would not be able to return to the old state social insurance system.

From the date of launching the system reform and with the increasing popularity of personal accumulations, a conclusion can be made that Lithuania's pension system consists of three parts:

1. State social insurance pension;

2. The payments from SoDra to private pension funds;

3. Additionally, a pension is accumulated voluntarily at life insurance companies or pension funds.

The payment to the state social insurance fund currently consists of the following:

- $31 \%$ of the wage, paid by the employer;

- $3 \%$ of the wage, paid by the employee.

When SoDra receives the $34 \%$ payment deducted from the wage of an employee, the payment is distributed and a part of money is directed private pension funds.

The part of money directed to private pension funds before 1 January 2013:

- In $2004-2.5 \%$ of gross wage;

- In $2005-3.5 \%$ of gross wage;

- In $2006-4.5 \%$ of gross wage;

- In 2007 and subsequent years - 5.5\% of wage.

Unfortunately, because of the difficult economic situation, transfers to private pension funds were reduced to $\mathbf{1 . 5} \%$ of the gross wage. In other words, the state was borrowing from private pension funds in order to lower the constantly increasing state social 
insurance fund deficit. This proves even more that private accumulation of pensions is unavoidable. However, private pension funds must be secured from constantly increasing debt of the state. All the Lithuanian residents have equal opportunities to additionally accumulate for pension, by concluding contracts with pension funds or life insurance companies and making payments out of their own assets. Only a minority of residents in Lithuania have life insurance or pension accumulation contracts and save for their old-age pension, despite a very favourable financial environment. The payments are exempt from income taxes (GPM 15\%). If an employer makes payments for pension accumulation or under an employee life insurance contract, these payments are not taxed. It is recognised as an allowed settlement and it reduces the profit tax.

\section{The size of the accumulated pension depends on the following:}

- Accumulation term (the younger a person, the more it is worth to accumulate);

- Salary (the higher the salary, the higher the payments);

- Investment income and taxes of a pension fund or life insurance company.

\section{Advantages of the pension reform:}

- A pension will be paid from two sources. People taking part in pension accumulation will receive pensions both from SoDra and from a pension fund. By paying the same payments to SoDra, people taking part in the reform will receive higher payments than before.

- All other social guarantees remain.

While participating in pension accumulation, all other social guarantees like unemployment, maternity or sickness support remain;

- All the money is inherited.

All the money accumulated in pension funds is inherited. In case of an accident the funds are inherited by family members.

\section{- Investment of money.}

Payments made by residents are not only collected, distributed and paid out, but also accumulated and invested. Every person accumulates pension for oneself. There is a big chance that in the result of investment, one will receive more money than they would from SoDra.

\section{Life Insurance, Its Benefit for the Insured and Their Family Members}

At the end of 2004, when the reform of the pension system had just started, there were more than 558 thousand participants who signed the contracts with pension funds. During the second stage of pension accumulation contract signing (from 1 January 2004 to 1 July 2004) 116255 contracts were signed. The majority - 36.6\% of people - signed their pension accumulation contracts during the first stage. More and more people realise that one cannot rely only on SoDra payments. An increasing number of pension accumulation contracts is signed each year. In addition, the distrust in the future of SoDra makes people look for additional means to increase their pension. 
In the developed Western European countries, the state pension amounts to about EUR 1000 - 1300. A private pension amounts to EUR 4000 - 7000. This amount of money has been accumulated over a long period of time. Different pension accumulation contracts are concluded for newborns, so that by paying small amounts, large sums are accumulated for the future pensioner. In Western Europe it was long customary for residents themselves to have to take care of their own future. Life insurance is a priority area for those people, while the Lithuanian residents are still of the opinion that it is far more important to insure a car, as it is a greater asset.

Life insurance and private pension funds are distributed to the third pension accumulation stage. This means that when one has life insurance or third-stage pension fund, they are obliged to make payments on their own.

\section{What are the differences between life insurance and third-level pension fund?}

Life insurance covers more services than a pension fund. Firstly, life insurance provides financial support for the injured and his or her family in case of an accident. With the help of life insurance, one can accumulate the required amount of money for a child's studies. If a "future student" looses the breadwinner, then he or she can receive monthly payments (orphan pension), and when they reach the age stated in the contract, they will be paid a monthly scholarship. In case of life insurance there is no need to arrange heritage documentation. This is the "fastest" money in case of an accident.

Third stage pension fund or accumulation for a pension in a life insurance company without acquiring additional protection is only for accumulating money for an oldage pension. In case of death, the accumulated amount is paid out and not the amount of life insurance money. For example, a chosen life insurance amount in a life insurance company is LTL 100000 and the accumulated capital in a pension fund is LTL 800. In the event of death of the beneficiary, the family will get LTL 100000 from the life insurance company and only LTL 800 from the pension fund. One can acquire a retirement annuity (life-long payment) and receive a life-long private pension only in a life insurance company. A pension fund does not perform these kinds of functions. This means that the money accumulated in a pension fund has to be transferred to a life insurance company, with which the annuity contract was concluded.

No one plans disasters or deaths. Unfortunately, everybody knows that they will not live forever. Also injuries and other unfortunate events occur to people very unexpectedly and nobody plans them. That is why life insurance "in everyone's shopping bag" always needs to be a priority "purchase". It is like that in all the developed countries. And this is how it is supposed to become in Lithuania.

\section{Pension Accumulation System Changes from 1 January 2013}

By the reform of the pension accumulation system and following the changes of the laws on pension accumulation from 2013, the following changes have come into force:

- From 1 January 2013 the amount of the payment directed from SoDra to the second level funds will rise from $1.5 \%$ to $2.5 \%$. 
- The period between 1 April and 30 November 2013 is an important period for those who accumulate pension funds, as they will have to choose one of the three options available.

- Starting from 2013, everyone concluding new pension accumulation contracts will be able to accumulate earlier -3 months after signing the contract.

- From 2013, a new opportunity arises to accumulate more, as some companies are reducing the administrative fees applied by them.

In 2013, everyone accumulating in the second level funds will have three choices:

1. "Go back to SoDra"

2. "Minimum accumulation"

3. "Maximum accumulation"

For those choosing the "Go back to SoDra" option

At old age they will receive money from SoDra only. The money already present in the pension accumulation account would not be supplemented with more payments from SoDra. However, the money in the fund will be invested further until a person reaches his or her pensionable age. This alternative is not beneficial for a future pensioner.

Figure 1. SoDra's pension forecast

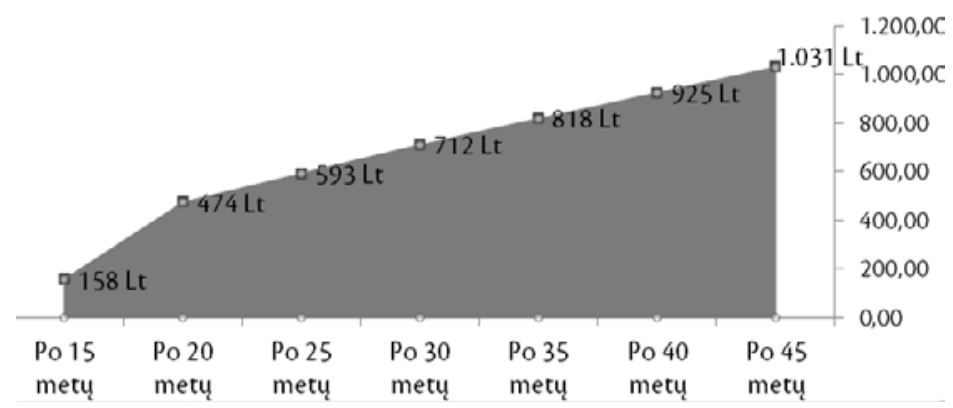

The displayed figures are based on the following assumptions: during the entire period before the pension, the amount of income is constant, work experience is counted excluding breaks, investment change is 5\%, administration fee and remittances to pension accumulation funds from SoDra are evaluated in accordance with the latest legal provisions.

It is foreseen that next year the SoDra deficit will reach LTL 1.7 billion, and at the end of 2013 the debt of the fund will be amount to LTL 11.3 billion. SoDra's income is LTL 12.2 billion, which means that SoDra is living a year ahead. Towards the future, the deficit of the SoDra budget will grow. An individual who chooses the "Go back to SoDra" option will be left without additional income source at old age, which would be accumulated in the second-level pension funds. The kind of pension that could be paid from SoDra based on different work experience and average wage is shown in Figure 1 (see above). 
However, in individual cases the "Go back to SoDra" option could be taken into consideration if a person is older than 55 and their official income is less than LTL 1000 per month. In that case, some individual calculations and evaluation of benefits should be made.

The "Minimum accumulation" option means that a participant agrees to a $2 \%$ transfer from SoDra, and thereby one's old-age pension would be reduced accordingly, by evaluating those $2 \%$. This alternative is somewhat better than the "Go back to SoDra" option, but it only insignificantly increases the size of income at old age (Fig. 2). An individual who receives an average wage and accumulates a pension in the system for 30 years receives a monthly pension that is LTL 150higher.

Figure 2. Pension size with $2 \%$ accumulation

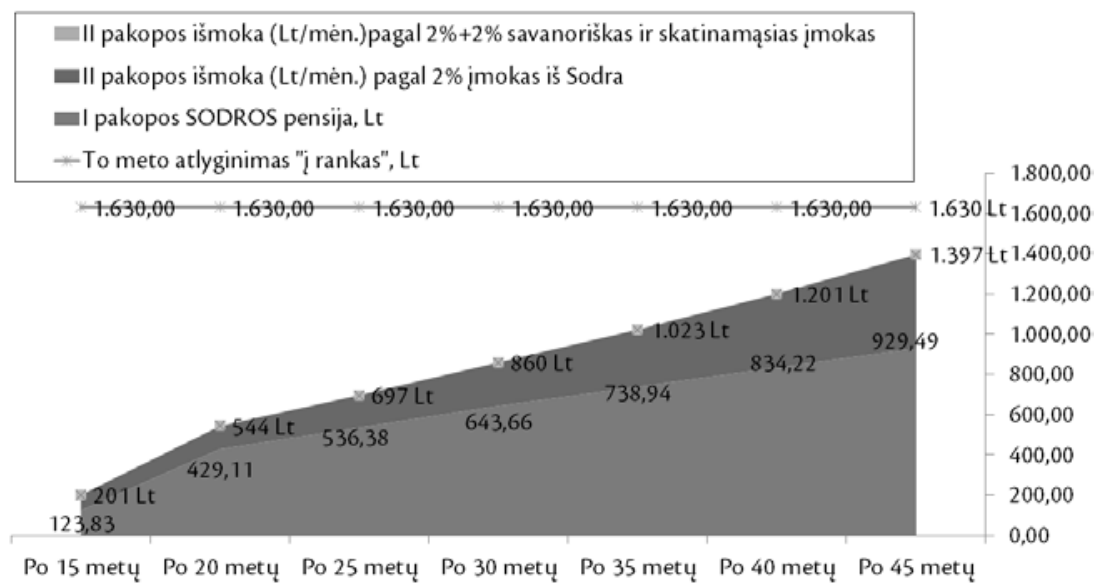

The "Maximum accumulation" option is also called the " $2+2+2$ " system. It consists of 3 different parts, transferred from different sources. First $2 \%$ - payment to pension accumulation account transferred from SoDra, second $2 \%$-voluntary payment from one's taxable income and the last $2 \%$ - additional state promotion, calculated on the basis of average income and transferred from the state budget. This system is more likely to increase one's income at old age, of course, if so preferred. For a person with an average wage who accumulates for 30 years, it can increase one's pension up to $70 \%$ - from LTL 712 (the size of the pension one would get if staying with SoDra, Fig. 1) up to LTL 1196 per month (Fig. 3). 


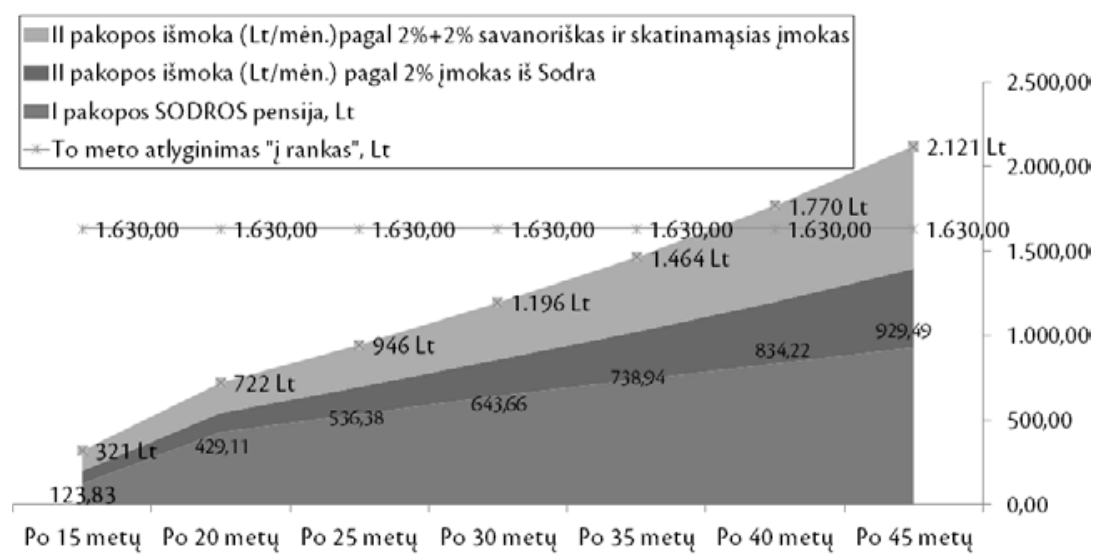

IMPORTANT: the " $2+2+2$ " system will be valid from 2016 and from 2014 the " $2+1+1$ " system will be applied, and by 2020 it would gradually turn into " $3,5+2+2$ " system.

According to the new legislative amendments, people receiving a pre-pension will be able to obtain the accumulated sum from pension funds at an earlier date.

In order to qualify for a pre-pension, a person needs to meet two conditions:

- one should have no more than 5 years left to the old-age pension.

- one needs to have at least 30 years of pensionable service.

\section{Conclusions}

1. The social insurance system is ineffective and needs to be rearranged.

2. For everyone with 10 and more years left to their old-age pension it is beneficial to participate in the pension system reform. Even a modest amount of LTL 10000 is better than a pension from SoDra that is a few litas higher.

3. Every citizen had to have full responsibility for their own future and for that of their family.

4. Life insurance should be among the highest priorities of every family.

5. To live a full-fledged life, one's pension should amount to $80 \%$ of the previous income. It is only possible by participating in the pension system reform and by additionally accumulating for yourself.

6. Life insurance ensures financial solidity not only after reaching old age, but also in cases of accident and sickness. 


\section{References}

1. Barauskaitè J.; Lezgovko, A. Economic and social life insurance aspects [interactive] [last accessed on 17-02-2013] <http://www.draudimas.com/?id=403034>.

2. Danske Bank. Why is it important to take care of the second-stage old-age pension? [interactive] [last accessed in June 2013] <http://www.danskebank.lt/pensija?gclid= CKOEjMiL17cCFeTLtAodTmQAaQ>.

3. Lazutka, R. Income, consumption and poverty, 2001 [interactive] [last accessed on 20-08-2013] <http://citavimas.lituanistikadb.lt/kurinio-perziura/pajamos-vartojimas-ir-skurdas/reference_list>.

4. Lazutka, R. et al. Poverty: methodology questions and level in Lithuania [interactive] [last accessed on 22-08-2013] <www.mruni.eu/lt/mokslo_darbai/sd/archyvas/dwn. php?id $=274347>$.

5. Lezgovko A.; Lastauskas, P. Nowadays insurance market in EU countries and Lithuania: analysis and perspectives // Economics, 2008 (82). - p. 127-146. - ISSN 1392-1258.

6. Main indicators of Lithuania. The Department of Statistics [interactive] [last accessed on 02-0-2013] <http://www.stat.gov.lt/lt/>.

7. MP Pension Funds. [interactive] [last accessed on 20-08-2013] <http://www.mppf.lt/ main.php/id/1.

8. No one needs pensioners [interactive] [last accessed in June 2013] <http://www.sarmatas.1t/02/niekam-nereikalingi-pensininkai/201306>.

9. Reform of the pension system and its implementation in Lithuania. [interactive] [last accessed in June 2013] <http://www.mokslai.lt/referatai/diplominis/pensiju-sistemos-reforma-ir-jos-vykdymas-lietuvoje-puslapis $25 . h t m l>$.

10. Seimas of Republic of Lithuania http://www.lrs.lt/pls/inter/lrs2lrv.home>.

11. SODRA. [interactive] [last accessed in 2013] <http://www.sodra.lt/ $>$.

12. Weekly „Tax News" article. [interactive] <http://www.mzinios.lt/lt/2013-06-17/ straipsniai/aktualijos/pensinis_amzius_ilginimas_iki_65eriu_metu.html>.

13. Wikipedia. [interactive] [last accessed on 20-08-2013] <http://lt.wikipedia.org/wiki/ Valstybinio_socialinio_draudimo_fondo_valdyba_prie_Socialin\%C4\%97s_apsaugos_ir_darbo_ministerijos> .

\section{PENSIJŲ FONDŲ IR GYVYBĖS DRAUDIMO İTAKA SENATVÉS PENSIJAI}

Santrauka. Lietuvoje, susidarius labai sudètingai „Sodros“ (socialinio aprūpinimo sistemos) padéčiai, Lietuvos Seimas, Vyriausybė ir paprasti žmonès vis labiau supranta, kad esamų ir būsimų pensininkų padètis reikalauja skubios pertvarkos. Tai patvirtina ir pensijų sistemos reformos pakeitimai, pradèti igyvendinti nuo $2013 \mathrm{~m}$. sausio 1 dienos.

Šiuo metu Lietuvos šalies ekonomikai itin didelị poveikị turejo ir tebeturi krizè, tačiau ir prieš ją Lietuvoje nebuvo susiklosčiusios tradicijos, kurios būdingos Vakarų šalims. Išsivysčiusiose Vakarų Europos šalyse tik gimusiam vaikui yra sudaroma pensijos fondo ir gyvybès draudimo su- 
tartis. Per ilgą laikotarpị nuo gimimo iki pensijos yra sukaupiama solidi privati suma, kuri leidžia pragyventi ir nekeisti susiklosčiusio gyvenimo stiliaus. Vokietijoje valstybinė pensija sudaro apie 1100 EUR, o privati - apie 4 500-5 500 EUR. Taigi, galime daryti išvadą, kad pagrindinis pragyvenimo šaltinis senatveje yra privati, o ne valstybine pensija.

Lietuvoje tuo tarpu yra atvirkščiai: pagrindinis pragyvenimo šaltinis senatvejje yra valstybinè pensija. Nors Lietuvoje valstybè ir skatina ilgalaikị taupymą, ịvesdama mokestines lengvatas asmenims, pasirašiusiems pensijos kaupimo bei gyvybès draudimo sutartis, to nepakanka. Gyventojų vidutinių pajamų mažejjimas neskatina skirti lèšų taupymui savo ateičiai, nes jų tiesiog nelieka. Didelę įtaką turi ir nedarbo šalyje didèjimas bei didelè emigracija. Todèl siekiant tolygaus senatvès pajamų formavimo būtina gerinti ekonominę šalies aplinką, verslo augimą, nedarbo mažinimą. Ne mažiau svarbus yra visuomenès švietimas, kad gyvenimas senatvèje labai priklauso ne tik nuo valstybès indèlio, bet ir nuo kiekvieno būsimo pensininko asmeninio indèlio.

Danguole JABLONSKIENE் - Lector at the Faculty of Economics and Finance Management, Department of Banking and Investments, Mykolas Romeris University. Research fields: guarantee of financial future.

Danguolė JABLONSKIENĖ - Mykolo Romerio universiteto Bankininkystès ir investicijų katedros lektorè. Moksliniai interesai: finansinis ateities užtikrinimas. 